\title{
PERCEPTION AND EXPECTATION DIFFERENCES TOWARD QUALITY OF OUT-PATIENTS REGISTRATION SERVICE
}

\author{
Lilik Anggar Sri Rahayuningsih'), Yeni Tri Utami²), Joko Parjianto²) \\ 1)Masters Program in Public Health, Universitas Sebelas Maret \\ ${ }^{2)}$ Diploma III of Medical Record and Health Information, Faculty of Health \\ Sciences, Universitas Duta Bangsa, Surakarta
}

\begin{abstract}
Background: Nowadays, patient satisfaction is one of the most important performance and quality outcome indicators for healthcare delivery services. Patient satisfaction refers to a patient assessment of the services received from the healthcare provider, which is affected by both the levels of expectation and experience of a patient. The purpose of this study was to examine perception and expectation differences toward quality of out-patients registration service.

Subjects and Method: A cross sectional study conducted at Pajang health center in Surakarta, Central Java, from May to July 2020. A sample of 99 out-patients was selected by accidental sampling. The dependent variables were patients perception and expectation. The independent variables were SERVQUAL dimensions, including reliability, responsiveness, assurance, emphaty, and tangibles. Mean differences of perception and expectation on each SERVQUAL dimensions were assessed by paired t-test.

Results: There was no difference between patient perception and expectation on the SERQUAL dimensions. Reliability (perception: $\mathrm{Mean}=21.30 ; \mathrm{SD}=2.84$ vs expectation: Mean= 21.19; $\mathrm{SD}=2.24 ; \mathrm{p}=0.392$ ). Responsiveness (perception: Mean= 21.13; $\mathrm{SD}=$ 3.13 vs expectation: $\mathrm{Mean}=21.19 ; \mathrm{SD}=2.49 ; \mathrm{p}=0.692$ ). Assurance (perception: $\mathrm{Mean}=$ 21.55; $\mathrm{SD}=3.09$ vs expectation: $\mathrm{Mean}=21.32 ; \mathrm{SD}=2.32 ; \mathrm{p}=0.193$ ). Emphaty (perception: Mean= 21.21; $\mathrm{SD}=3.13$ vs expectation: $\mathrm{Mean}=21.67 ; \mathrm{SD}=4.97 ; \mathrm{p}=0.311)$. Tangibles (perception: Mean= 21.85; $\mathrm{SD}=3.08$ vs expectation: $\mathrm{Mean}=21.63 ; \mathrm{SD}=2.45$; $\mathrm{p}=0.109)$.
\end{abstract}

Conclusion: There is no difference between patient perception and expectation on the SERQUAL dimensions (reliability, responsiveness, assurance, emphaty, and tangibles).

Keywords: expectation, perception, SERVQUAL, health care service administration

\section{Correspondence:}

Lilik Anggar Sri Rahayuningsih. Masters Program in Public Health, Universitas Sebelas Maret. Jl. Ir. Sutami 36A, Surakarta 57126, Central Java, Indonesia. Email: lilikanggar@gmail.com. 